\title{
Prediction of milk yield from udder circumference and distance between teats in West African Dwarf and Red Sokoto goats
}

\author{
M.N. Bemji ${ }^{1 *}$ and O.A. Osinowo ${ }^{2}$ \\ 'Department of Animal Breeding and Genetics, University of Agriculture, P.M.B. 2240, Abeokuta, Nigeria \\ ${ }^{2}$ Department of Animal Physiology, University of Agriculture, P.M.B. 2240, Abeokuta, Nigeria \\ ${ }^{*}$ Corresponding Author
}

\begin{abstract}
Udder circumference (UC) and distance between teats (DBT) measured before and after.milking were used to determine CUC (UC before milking minus UC afier milking) and CDT (DBT before milking minus $D B T$ after milking). All four parameters were utilized as independent variables in two standard regression models (lineac and multiple linear) to develop equations for prediction of daily milk yield from 202 weekly records of 17 lactating does, consisting of 8 West African Dwarf (WAD) and 9 Red Sokoto (RS) goats. WAD and RS goats had similar mean values for daily milk yield $(270.34 \pm 12.47 \mathrm{ml}$ vs $265.26 \pm 14.5 \mathrm{lml})$ and $U C(28.49 \pm 0.33 \mathrm{~cm}$ vs $28.81 \pm 0.39 \mathrm{~cm})$, but differed very significantly $(P<0.001)$ in DBT $(7.33 \pm 0.11 \mathrm{~cm}$ and $5.82 \pm 0.13 \mathrm{~cm})$. Both models had significant $(P<0.001) R^{2}$ values ranging from 0.244 to 0.757 . UC was the best index of milk yield $\left(R^{2}=0.688\right)$ followed by CUC $\left(R^{2}=0.476\right)$ in the linear regression equation while DBT and CDT yielded lower $R^{2}$ values (0.244 vs 0.258). Inclusion of all four parameters in the multiple linear regression equation yielded the highest $R^{2}(0.757)$. The predictive equation was $Y=$ $441.443+25.739 X_{1}+23.349 X_{2}-21.265 X_{3}+61.080 X_{4}$ in which $Y$ is milk yield, $X_{1}, \ldots, X 4$ represent $U C$, $C U C, D B T$ and CDT respectively. Positive and significant $(P<0.001)$ phenotypic correlations were observed between UC and milk yield (0.759), CUC and milk yield (0.690), DBT and milk yield (0.498), CDT and milk yield (0.508). In the current practice of collecting weekly records, early prediction of future milk production from udder circumference measured prior to milking will be accurate using linear regression predictive equation. Alternatively, if more traits related to udder size such as UC, CUC, DBT and CDT are incorporated as independent variables in multiple linear regression equation, milk production could be predicted with better accuracy.
\end{abstract}

Keywords: Goats, Udder circumference, Distance between teats, Milk yield, Prediction 


\section{Introduction}

Increasing importance is being attached to the conformation traits of goat udder because of their influence on udder health, milk yield and applicability to mechanical milking. Linzell (1975) stated that an organ that increases and regresses in size and function could give clues about the control of growth as well as positive and negative feedback mechanisms. The mammary tissue is remarkable in its elastic properties and its secretory cells which are plastic in nature. They alter their shape all the time from tall columnar when empty to squamous when full. Extensive proliferation and death of cells in the mammary gland occur during pregnancy and lactation (Dijkstra et al. 1997). Udder dynamics in goats (milk production, milking time and rate) are traits with adequate genetic variation to allow for selection responses (Montaldo and MartinezLozano, 1993). Milk synthesis naturally commences following parturition and rises to a maximum at 2 weeks in goats (Ehoche and Buvanendran, 1983) and 5-6 weeks in cows (Linzell, 1975) and then declines exponentially until dry. The structure and functioning rhythm of the udder is controlled by the reproductive hormones, particularly of the ovary, the hypophysis and placenta (Schams et al., 1984). Udder biometrics has been shown to be related to milk yield in cattle (Linzell, 1975; Singh et al., 1993; Prajapati et al., 1995), sheep (Labussiere 1988; Agbede et al., 1997) and goats (Linzell, 1975; Peris et al., 1999; James and Osinowo, 2004). In cows and goats, udder blood flow and milk yield per gram tissue are closely associated (Linzell, 1975; Morand-Fehr et al.. 1982). The rate of milk secretion in the udder is very slow, about $2 \mathrm{cc}$ per gram tissue per day (Linzell, 1975). Maximum rate of secretion is the same per gram of mammary tissue in mice and cows, implying that milk yield is directly related to mammary gram weight. James and Osinowo (2004) obtained positive and significant phenotypic correlations between partial daily milk yield and udder dimensions (length, width, circumference and volume), distance between teats, teat height to the ground, teat length, teat width and teat circumference, measured prior to milking in West African Dwarf and Red Sokoto goats. In view of the fact that udder circumference and distance between teats were most strongly correlated with partial daily milk yield, the main objective of this study was to develop predictive equations for daily milk yield using both dimensions and their changes as independent variables in both linear and multiple linear regression equations.

\section{Materials and Methods}

Animals and management

This study was conducted at the University of Agriculture, Abeokuta, located within the humid zone of South-West Nigeria. It receives a mean precipitation of $1,112.7 \mathrm{~mm}$ with seasonal distribution approximated at $110.9 \mathrm{~mm}$ in the late-dry season (Jan.-March), $462.1 \mathrm{~mm}$ in the early-wet season (April-June), $376.6 \mathrm{~mm}$ in the late-wet season (July-Sept.) and $163.1 \mathrm{~mm}$ in the early-dry season (Oct.-Dec.). Relative humidity averages $82 \%$ throughout the year. A total of 17 
does comprising 8 WAD and 9 RS were used for the study. The animals were in their first to third lactation and intensively managed in cross ventilated pens with slatted floor. Nutrition was mainly based on zero grazing on pasture species comprising Panicum maximum, Pennisetum purpureum and Stylosanthes hamata given ad libitum. They were supplemented on daily basis with concentrate feed of about $15 \% \mathrm{CP}$ compounded from maize $(25 \%)$, wheat offal $(28.5 \%)$, rice bran $(25 \%)$, palm kernel cake $(20 \%)$, bone meal $(1 \%)$ and salt $(0.5 \%)$ to ensure that nutritional requirements were met. Animals had access to water ad libitum and were routinely de-wormed and treated against ectoparasites.

Measurement of udder circumference (UC), distance between teats (DBT) and milk yield

Following parturition, UC and DBT were measured in $\mathrm{cm}$ prior to and after milking at weekly intervals from fourth day post partum with a flexible canvas tape rule. UC was measured as the distance round the widest point of udder, while DBT was taken by placing the tape between the two teats at the point of attachment to the udder and reading off the distance covered in $\mathrm{cm}$ (Fig. 1). Change in udder circumference (CUC) was calculated as the difference between UC before milking and UC after milking. Change in distance between teats (CDT) was similarly calculated as the difference between DBT before milking and DBT after milking. Live weights of does were also taken prior to milking. To determine milk yield, does were hand-milked twice daily (7.00 and 15.00 h) following 8-hour separation from their kids. The initial milking was to empty the udder of any milk retained after suckling by the kids during the night. Prior to final milking ( 8 hours after separation), the udder was washed and dried with a towel. The doe was then rapidly milked until the amount of milk obtained at each stripping was less than one $\mathrm{ml}$. Total yield $(\mathrm{ml})$ for 24-hour period was calculated in proportion to the time interval between initial and final milking, i.e. 3 times 8 -hour yield. This was based on reports that milk production in the mammary gland of goats is constant throughout the day (Linzell, 1966). Records of three does with stillbirth and two infected with mastitis were discarded from 22 lactations.

\section{Statistical analysis}

A total of 202 weekly records generated from 17 lactations were taken into analysis to evaluate the effects of breed and environmental factors on milk yield and udder dimensions studied. The Multivariate General Linear Model of Systat program, release 5.02 (Systat, 1992) was utilized in the analysis. Doe live weight was included as a covariate in model 1 (Eq. (1)):

$Y_{i j k l m n}=\mu+B_{i}+W_{j}+S_{k}+P_{1}+L_{i n}+b W T+E_{i j k l m n}$ ......(1)

where $\mathrm{Y}_{\mathrm{ij} \mathrm{kl} \mid \mathrm{mo}}=$ milk yield, $\mathrm{ml}$ or any of the udder dimensions, $\mathrm{cm}, \mu=$ mean,

$B_{i}=$ effect of $i^{\text {th }}$ dam breed $(i=$ West African Dwarf or Red Sokoto) 
$W_{j}=$ effect of $j^{\text {th }}$ week of lactation $(j=1,2, \ldots$, 12),

$\mathrm{S}_{\mathrm{k}}=$ effect of $\mathrm{k}^{\text {th }}$ season of kidding ( $\mathrm{k}=$ late-dry, early-wet, late-wet or early-dry)

$P_{1}=$ effect of $l^{\text {th }}$ parity of dam $(I=1,2$ or 3$)$

$\mathrm{L}_{\mathrm{m}}=$ effect of $\mathrm{m}^{\text {th }}$ litter size $(\mathrm{m}=1$ or 2$)$

$b=$ regression coefficient of doe live weight on milk yield

$\mathrm{E}_{\mathrm{ijklmn}}=$ random error.

The data were adjusted using constant estimates generated from least squares analysis in the following equation (Eq. (2)):

$$
\gamma=\mathrm{Y}-\mathrm{b}_{\mathrm{i}}-\mathrm{w}_{\mathrm{j}}-\mathrm{s}_{\mathrm{k}}-\mathrm{p}_{1}-\mathrm{l}_{\mathrm{m}}
$$

where $\gamma=$ adjusted value

$\mathrm{Y}=$ unadjusted value

$b_{i}=$ adjustment factor for the effect of $i^{\text {th }}$ breed $(\mathrm{i}=1-2)$

$w_{j}=$ adjustment factor for the effect of $j^{\text {th }}$ week $(j=1-12)$

$s_{k}=$ adjustment factor for the effect of $k^{\text {ih }}$ season ( $k$ = late-dry, early-wet, late-wet or early-dry)

$p_{1}=$ adjustment factor for the effect of $1^{\text {th }}$ parity $(1=1-3)$

$\mathrm{l}_{\mathrm{m}}=$ adjustment factor for the effect of $\mathrm{m}^{\text {th }}$ litter size $(m=1-2)$

Linear regression and multiple linear regression equations with two or more variables were used, with inclusion of unadjusted UC, DBT, CUC and $\mathrm{CDT}$ as independent variables to generate constants for prediction of milk yield. The equations are as follows:

Linear regression (Eq. (3)): $\mathrm{Y}=\mathrm{A}+\mathrm{B} X$

Multiple linear regression (Eq. (4)): $\mathrm{Y}=\mathrm{A}+\mathrm{B}_{1} X_{l}+$ $\mathrm{C}_{2} X_{2}+\mathrm{D}_{3} X_{3}+\mathrm{E}_{4} X_{4}$

where:

$\mathrm{Y}=$ unadjusted milk yield, $\mathrm{ml}$

$\mathrm{A}, \mathrm{B}, \mathrm{C}, \mathrm{D}$ or $\mathrm{E}=$ rate of change in milk yield with udder dimension

$X_{1}, \ldots, X_{4}=$ unadjusted independent variables (UC, DBT, CUC or CDT).

The effect of breed on constants generated for individual goats was not significant. Evaluation of the model was mainly based on the coefficient of determination or $\mathrm{R}^{2}$ values. Pearson's productmoment correlation coefficients between adjusted milk yield and UC, DBT, CUC and CDT were estimated using the CORR procedure (Systat, 1992).

\section{Results}

Least squares means and standard errors for udder measurements and milk yield are shown in Table 1. West African Dwarf and Red Sokoto goats had similar mean values for daily milk yield $(270.34 \pm 12.47 \mathrm{ml}$ vs $265.26 \pm 14.51 \mathrm{ml}(\mathrm{P}>0.05))$ and $U C(28.49 \pm 0.33 \mathrm{~cm}$ vs $28.81 \pm 0.39 \mathrm{~cm}$ $(P>0.05))$, while differing significantly $(\mathrm{P}<0.001)$ in DBT $(7.33 \pm 0.11 \mathrm{~cm}$ vs $5.82 \pm 0.13$ $\mathrm{cm}$ ). All udder measurements (UC, CUC, DBT, CDT) and milk yield varied very highly significantly $(\mathrm{P}<0.001)$ in a decreasing order 


\section{Bemji and Osinowo}

Table 1: Least squares means $( \pm S E$ ) of udder measurements and daily milk yield according to the effects of breed, week of lactation, season, parity and litter size in goats

\begin{tabular}{|c|c|c|c|c|c|c|c|}
\hline \multirow[b]{2}{*}{ Variable } & \multirow[b]{2}{*}{ Sub-class } & \multirow[b]{2}{*}{ No. } & \multicolumn{5}{|c|}{ Least squares means $(+\mathrm{SE})$} \\
\hline & & & UC. $\mathrm{cm}$ & DBT, $\mathrm{cm}$ & $\mathrm{CUC}, \mathrm{cm}$ & $\mathrm{CDT}, \mathrm{cm}$ & Milk yield, $\mathrm{ml}$ \\
\hline Breed & WAD & 94 & $28.49 \pm 0.33^{\mathrm{a}}$ & $7.33 \pm 0.11^{\mathrm{a}}$ & $2.57+0.12^{\mathrm{a}}$ & $1.04 \pm 0.05^{\mathrm{a}}$ & $270.34 \pm 12.47^{1}$ \\
\hline & RS & 108 & $28.81 \pm 0.39^{\circ}$ & $5.82 \pm 0.13^{b}$ & $2.04 \pm 0.14^{6}$ & $0.75+0.06^{b}$ & $265.26 \pm 14.51^{2}$ \\
\hline \multirow[t]{11}{*}{ Week } & 1 & 17 & $34.03+0.69^{\mathrm{a}}$ & $8.27 \pm 0.23^{a}$ & $2.95 \pm 0.25^{\text {ils }}$ & $1.37 \pm 0.10^{\mathrm{a}}$ & $410.76+25.65^{\mathrm{a}}$ \\
\hline & 2 & 17 & $31.99 \pm 0.69^{\mathrm{b}}$ & $7.60 \pm 0.23^{17}$ & $2.87 \pm 0.25^{\mathrm{a}}$ & $1.05+0.10^{\mathrm{bc}}$ & $388.00 \pm 25.65^{\mathrm{ab}}$ \\
\hline & 3 & 17 & $30.43+0.69^{\mathrm{bc}}$ & $7.30 \pm 0.23^{\mathrm{bc}}$ & $2.85 \pm 0.25^{\mathrm{ab}}$ & $1.14 \pm 0.10^{\mathrm{ab}}$ & $334.35 \pm 25.65^{\mathrm{bx}}$ \\
\hline & 4 & 17 & $30.02 \pm 0.69^{9}$ & $7.06 \pm 0.23^{\mathrm{bcc}}$ & $2.68 \pm 0.25^{\text {atr }}$ & $1.07 \pm 0.10^{\mathrm{bc}}$ & $313.00+25.65^{\mathrm{cd}}$ \\
\hline & 5 & 17 & $28.95 \pm 0.69^{\text {cd }}$ & $6.68+0.23^{\mathrm{cdl}}$ & $2.15 \pm 0.25^{\mathrm{bx}}$ & $0.90 \pm 0.10^{\text {bed }}$ & $275.41 \pm 25.65^{\text {cde }}$ \\
\hline & 6 & 17 & $28.69+0.69^{\mathrm{cd}}$ & $6.55 \pm 0.23^{\text {de }}$ & $2.13 \pm 0.25^{b x}$ & $0.84 \pm 0.10^{\text {bed }}$ & $258.11 \pm 25.65^{\mathrm{d} z}$ \\
\hline & 7 & 17 & $27.85 \pm 0.69^{\text {de }}$ & $6.33 \pm 0.23^{e f}$ & $2.25 \pm 0.25^{\mathrm{atc}}$ & $0.85 \pm 0.10^{\mathrm{bcd}}$ & $243.82 \pm 25.65^{\text {def }}$ \\
\hline & $\begin{array}{l}8 \\
9\end{array}$ & 17 & $27.42 \pm 0.69^{\text {te }}$ & $6.23 \pm 0.23^{\mathrm{ef}}$ & $2.17+0.25^{\mathrm{abc}}$ & $0.77 \pm 0.10^{\mathrm{cd}}$ & $239.23 \pm 25.65^{\text {deffy }}$ \\
\hline & $\begin{array}{l}9 \\
10\end{array}$ & 17 & $27.12 \pm 0.69^{\mathrm{de}}$ & $6.04+0.23^{\text {tf }}$ & $2.27 \pm 0.25^{\text {abc }}$ & $0.71 \pm 0.10^{\mathrm{d}}$ & $213.82+25.65^{\mathrm{efg}}$ \\
\hline & $\begin{array}{l}10 \\
11\end{array}$ & 17 & $26.31 \pm 0.69^{\mathrm{ef}}$ & $5.77 \pm 0.23^{\mathrm{fg}}$ & $1.88 \pm 0.25^{\mathrm{c}}$ & $0.71 \pm 0.10^{\mathrm{d}}$ & $198.47 \pm 25.65^{\mathrm{ets}}$ \\
\hline & $\begin{array}{l}11 \\
12\end{array}$ & 16 & $25.94 \pm 0.71^{\mathrm{et}}$ & $\begin{array}{l}5.73 \pm 0.34^{\text {fy }} \\
5.35+0.34^{\mathrm{s}}\end{array}$ & $\begin{array}{l}1.75+0.26^{\mathrm{C}} \\
169+0.26^{\mathrm{c}}\end{array}$ & $\begin{array}{l}0.73+0.12^{\mathrm{d}} \\
0.59+0.12^{\mathrm{d}}\end{array}$ & $\begin{array}{l}174.53 \pm 26.49^{93} \\
164.12+26.49^{9}\end{array}$ \\
\hline \multirow{4}{*}{ Season } & & & $25.04 \pm 0.11$ & & & & \\
\hline & $\begin{array}{l}\text { Late dry } \\
\text { Early wet }\end{array}$ & 48 & $28.73 \pm 0.46^{\mathrm{b}}$ & & $2.46 \pm 0.17^{\mathrm{a}}$ & $\begin{array}{l}0.69+0.07^{\mathrm{b}} \\
0.79+0.06^{\mathrm{b}}\end{array}$ & \\
\hline & $\begin{array}{l}\text { Early wet } \\
\text { Late wet }\end{array}$ & 58 & $28.23 \pm 0.37^{b}$ & $\begin{array}{l}5.75+0.13^{c} \\
6.83+0.16^{b}\end{array}$ & $\begin{array}{l}1.99 \pm 0.14 \\
2.18+0.18^{\text {alt }}\end{array}$ & $\begin{array}{l}0.79+0.06^{\mathrm{b}} \\
0.76+0.07^{\mathrm{b}}\end{array}$ & $\begin{array}{l}235.77+13.84^{\mathrm{a}} \\
294.02+17.97^{\mathrm{a}}\end{array}$ \\
\hline & $\begin{array}{l}\text { Late wet } \\
\text { Early dry }\end{array}$ & 60 & $29.91+0.48^{a}$ & & $\begin{array}{l}2.18 \pm 0.18 \\
2.59+0.20^{\mathrm{a}}\end{array}$ & $\begin{array}{l}0.76+0.07^{\mathrm{b}} \\
1.34+0.08^{\mathrm{a}}\end{array}$ & $\begin{array}{l}294.02+17.97^{\mathrm{a}} \\
273.50+20.15^{\mathrm{a}}\end{array}$ \\
\hline \multirow{3}{*}{ Parity } & & & $\begin{array}{c}28.73 \pm 0.54^{\prime \prime} \\
\therefore\end{array}$ & & & & \\
\hline & $\begin{array}{l}1 \\
2\end{array}$ & 132 & $26.55 \pm 0.36^{\mathrm{b}}$ & $6.21 \pm 0.12^{\mathrm{b}}$ & $2.57+0.13^{\mathrm{a}}$ & $0.98+0.05^{\mathrm{a}}$ & $242.66 \pm 13.51^{b}$ \\
\hline & $\begin{array}{l}2 \\
3\end{array}$ & 36 & $30.05 \pm 0.58^{\mathrm{a}}$ & $6.47 \pm 0.20^{b}$ & $\begin{array}{l}1.98+0.21^{\mathrm{a}} \\
236+0.19^{\mathrm{a}}\end{array}$ & $\begin{array}{l}0.88+0.09^{\mathrm{at}} \\
0.83+0.08^{\mathrm{a}}\end{array}$ & $\begin{array}{l}273.47 \pm 21.75^{\mathrm{a}} \\
287.28+19.91^{\mathrm{a}}\end{array}$ \\
\hline & & 34 & $29.35 \pm 0.53^{\mathrm{a}}$ & $7.04 \pm 0.18^{\mathrm{a}}$ & & & $287.28 \pm 19.91^{\mathrm{z}}$ \\
\hline \multirow{2}{*}{$\begin{array}{l}\text { Litter } \\
\text { size }\end{array}$} & 1 & 130 & $28.91 \pm 0.91^{\text {a }}$ & $6.48+0.14^{\mathrm{a}}$ & $2.15+0.15^{a}$ & $0.70+0.06^{\mathrm{b}}$ & $237.85+15.36^{\mathrm{a}}$ \\
\hline & 2 & 72 & $28.38 \pm 0.38^{\prime \prime}$ & $6.67 \pm 0.13^{\mathrm{a}}$ & $2.46 \pm 0.14^{a}$ & $1.01 \pm 0.06^{\mathrm{a}}$ & $297.75 \pm 14.71^{\mathrm{b}}$ \\
\hline
\end{tabular}

$$
0.565 \quad 0.235
$$

0.181

0.056

18.011

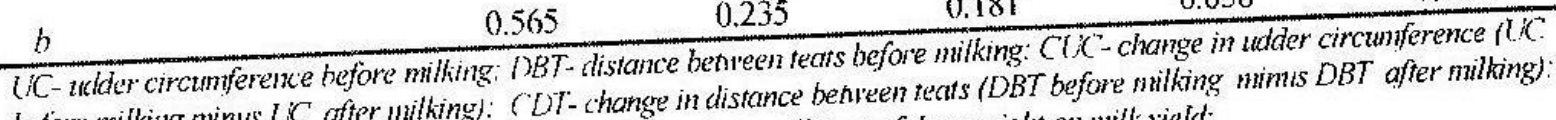
$b=$ Regiession coefficient of dam weight on milk yield:

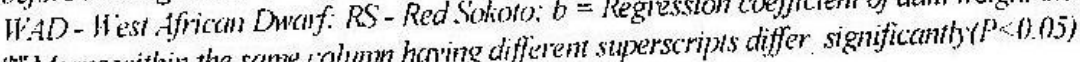

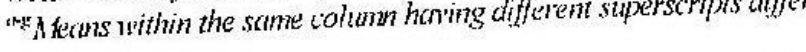
throughout lactation. Seasonal influence was very highly significant $(\mathrm{P}<0.001)$ for $\mathrm{UC}, \mathrm{DBT}$ and CDT, while significant $(\mathrm{P}<0.05)$ for $\mathrm{CUC}$ and not significant $(P=0.07)$ for milk yield. The seasonal trend in UC closely followed the trend in milk yield with indication that highest mean estimates were obtained during the late wet season while the least estimates were recorded during the early wet season. Estimates generally increased with parity of doe for $\mathrm{UC}(\mathrm{P}<0.001)$, DBT $(\mathrm{P}<0.001)$ and milk yield $(\mathrm{P}>0.05)$. The influence of litter size on milk yield was significant $(\mathrm{P}<0.01)$. Milk yield was higher $(20 \%)$ in does that kidded twins. This also reflected a higher $(22 \%)$ change $(\mathrm{P}<0.05)$ in distance between teats. No significant 
interactions were however observed between any of the factors. The effect of doe live weight on all variables studied was significant $(\mathrm{P}<0.001)$ with positive regression coefficients.

Predictive equations (Table 2) showed that there were significant $(\mathrm{P}<0.001)$ regressions in all models with $\mathrm{R}^{2}$ ranging from 0.244 to 0.757 . Considering individual traits, $\mathrm{UC}$ had the best fit in the linear regression equation $\left(\mathrm{R}^{2}=0.668\right.$ (Fig. 2)), followed by CUC ( $\mathrm{R}^{2}=0.476$ (Fig. 3)), DBT $\left(\mathrm{R}^{2}=0.244\right.$ (Fig. 4)) and CDT $\left(\mathrm{R}^{2}=0.258\right.$ (Fig. 5)). The magnitude of $\mathrm{R}^{2}$ generally improved with the use of two or more traits in the multiple linear equations. The best fit was obtained with the inclusion of four variables. The predictive equation (Eq. (5)) is as follows:

$$
\begin{aligned}
Y= & -441.443+25.739 X_{1}+23.349 X_{2}- \\
& 21.265 X_{3}+61.080 X_{4}\left(\mathrm{R}^{2}=0.757\right)
\end{aligned}
$$

where, $\mathrm{Y}=$ milk yield

$X_{1}, X_{2}, X_{3}$ and $X_{4}=\mathrm{UC}, \mathrm{CUC}, \mathrm{DBT}$ and CDT, respectively.

Correlations between udder measurements and milk yield are shown in Table 3 . Positive and significant $(\mathrm{P}<0.001)$ phenotypic correlations were observed between UC and milk yield (0.759), CUC and milk yield (0.690), DBT and milk yieId (0.498), CDT and milk yield (0.508).

\section{Discussion}

The decrease in udder traits throughout lactation with accompanying decrease in milk production

\begin{tabular}{|c|c|c|c|}
\hline Regression type & Independent variable(s) & Predictive equation & $\mathrm{R}^{2}$ \\
\hline 1. Linear & $\mathrm{UC}$ & $Y=-531.313+28.055 X$ & $0.668 * * *$ \\
\hline $\mathrm{Y}=\mathrm{A}+\mathrm{B} X$ & CUC & $Y=55.769+82.156 X$ & $0.476 * * *$ \\
\hline \multirow{2}{*}{ - } & DBT & $Y=5.168+38.942 X$ & $0.244 * * *$ \\
\hline & CDT & $\mathrm{Y}=138.846+127.006 X$ & $0.258 * * *$ \\
\hline \multicolumn{4}{|l|}{ 2. Multiple linear } \\
\hline i. Two variables & $\operatorname{UC}\left(X_{1}\right) \cdot \operatorname{CUC}\left(X_{2}\right)$ & $Y=-445.259+22.468 X_{1}+29.583 X_{2}$ & $0.722 * * *$ \\
\hline \multirow[t]{3}{*}{$\mathrm{Y}=\mathrm{A}+\mathrm{B}_{1} \mathrm{X}_{1}+\mathrm{C}_{2} X_{2}$} & $\mathrm{UC}\left(X_{1}\right), \mathrm{DBT}\left(X_{2}\right)$ & $Y=-539.247+29.566 X_{1}-5.467 X_{2}$ & $0.691 * * *$ \\
\hline & $\operatorname{CUC}\left(X_{1}\right), \operatorname{CDT}\left(X_{2}\right)$ & $Y=42.405+69.656 X_{1}+49.720 X_{2}$ & $0.505^{* * *}$ \\
\hline & $\operatorname{DBT}\left(Y_{1}\right), \operatorname{CDT}\left(X_{2}\right)$ & $Y=46.239+21.416 X_{1}+79.475 X_{2}$ & $0.269 * * *$ \\
\hline \multicolumn{4}{|l|}{ ii. Three variables } \\
\hline \multicolumn{4}{|l|}{$\mathrm{Y}=\mathrm{A}+\mathrm{B}_{1} X_{1}+\mathrm{C}_{2} X_{2}^{+}$} \\
\hline \multirow[t]{4}{*}{$\mathrm{D}_{3} \mathrm{~K}_{\xi}$} & $\operatorname{UC}\left(X_{1}\right), \operatorname{DBT}\left(X_{2}\right), \operatorname{CDT}\left(X_{3}\right)$ & $Y=-497.400+29.435 X_{1}-22.098 X_{2}+76.313 X_{3}$ & $0.738^{* * *}$ \\
\hline & $\operatorname{UC}\left(X_{1}\right), \operatorname{CUC}\left(X_{2}\right), \operatorname{DBT}\left(X_{3}\right)$ & $\mathrm{Y}=-451.558+24.491 X_{1}+31.837 X_{2}-8.857 X_{3}$ & $0.730 * * *$ \\
\hline & $\operatorname{UC}\left(X_{1}\right), \operatorname{CUC}\left(X_{2}\right), \operatorname{CDT}\left(X_{3}\right)$ & $Y=-437.268+21.799 X_{i}+24.670 X_{2}+25.769 X_{3}$ & $0.730 * * *$ \\
\hline & $\operatorname{CUC}\left(X_{l}\right) \cdot \operatorname{DBT}\left(X_{2}\right), \operatorname{CDT}\left(X_{3}\right)$ & $\mathrm{Y}=10.903+67.057 X_{1}+8.118 X_{2}+34.558 X_{3}$ & $0.510^{* * *}$ \\
\hline \multicolumn{4}{|l|}{ iii. Four variables } \\
\hline \multicolumn{4}{|l|}{$\mathrm{Y}=\mathrm{A}+\mathrm{B}_{1} \mathrm{X}_{1}+\mathrm{C}_{2} \mathrm{l}_{2}+$} \\
\hline $\mathrm{D}_{3} X_{3}+\mathrm{E}_{4} \mathrm{Y}_{4}$ & $\begin{array}{l}\operatorname{UC}\left(X_{1}\right), \operatorname{CUC}\left(X_{2}\right), \operatorname{DBT}\left(X_{3}\right), \\
\operatorname{CDT}\left(X_{4}\right)\end{array}$ & $\begin{aligned} \mathrm{Y}= & -441.443+25.739 X_{i}+23.349 X_{2}-21.265 X_{3} \\
& +61.080 X_{i}\end{aligned}$ & $0.757 * * *$ \\
\hline
\end{tabular}

Table 2: Predictive equations for daily milk yield in goats 


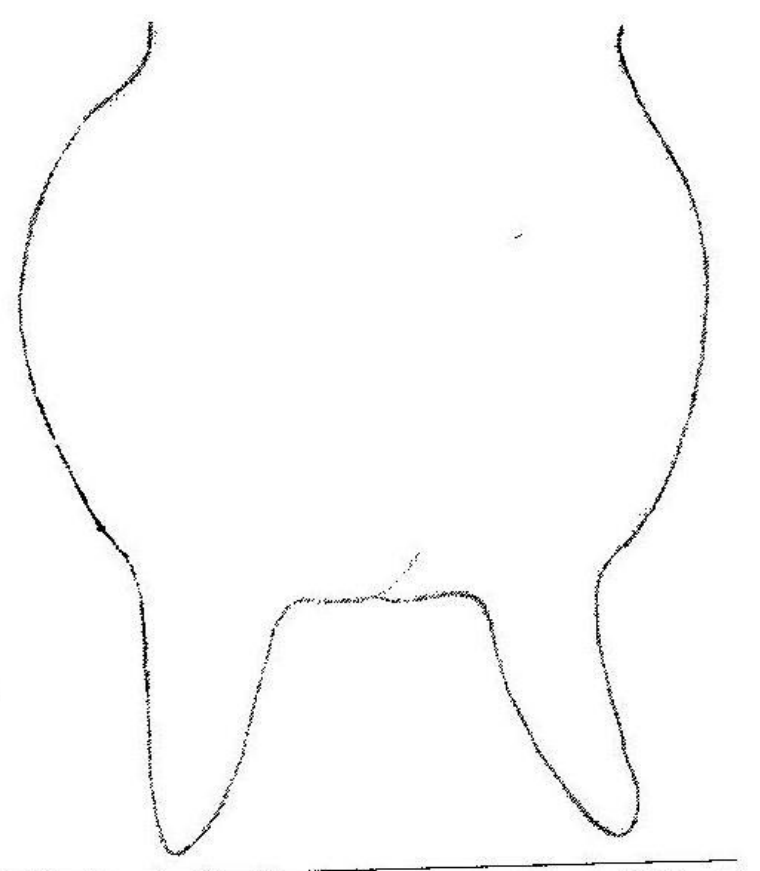

Fig. 1.Measurement of udder circumference (UC) and distance between teats (DBT) in goats as proposed Amao (1999).

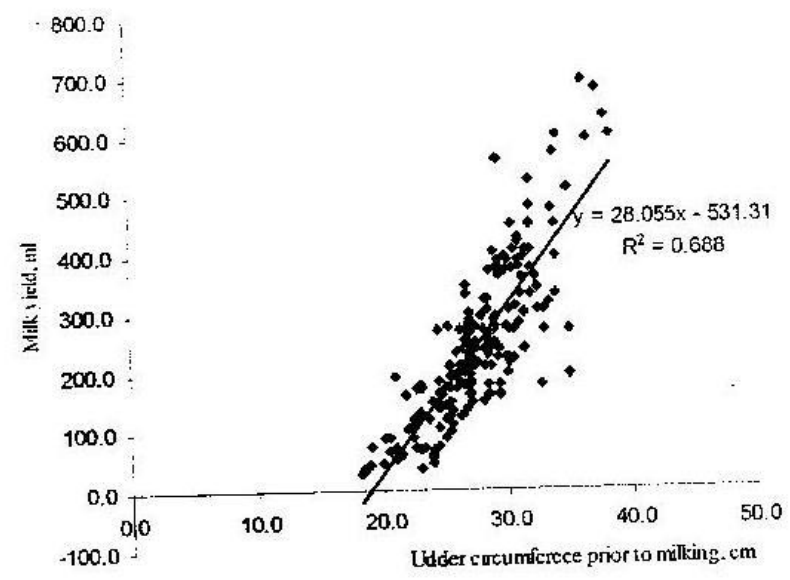

Fig. 2. Relationship between udder circunference prior to minking and rivik yield in goats

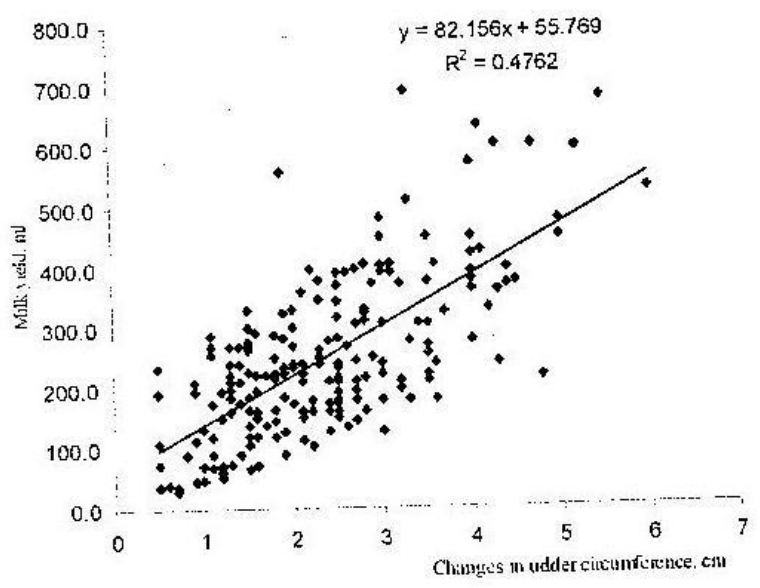

Fig. 3. Relatrouship between clanges in udder circunference and mitik yield in goals

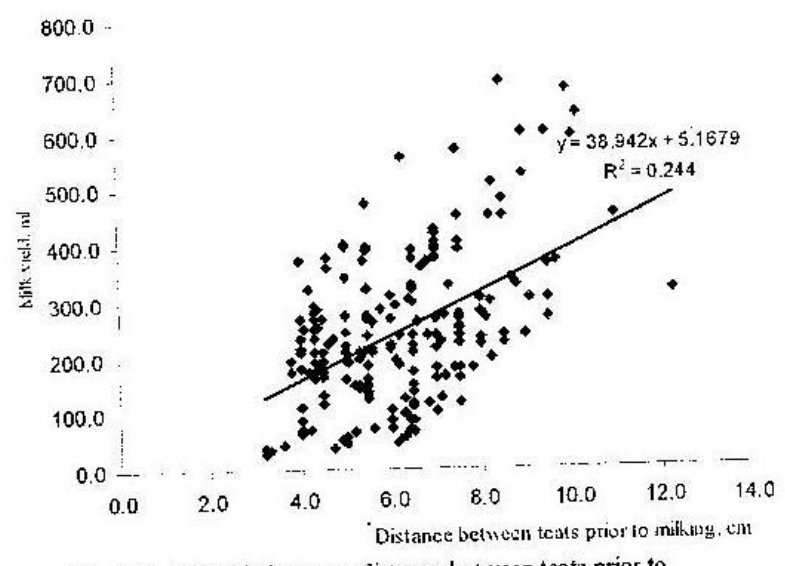

Firy 4. Relationship between distance betiveen teats prior to milking and milk yieid in goats

was probably as a result of the decrease in udder secretory tissues (Knight and Wilde, 1993; Dijkstra et al., 1997; Peris et al., 1999). Earlier, Linzell (1975) observed that milk yield varies more than udder size so that the yield per gram of tissue increased in early lactation and decreased markedly in late lactation as a result of both loss of secretory tissue and fall in the rate of secretion per cell, which is most likely to account for the observed gradual decline in milk 


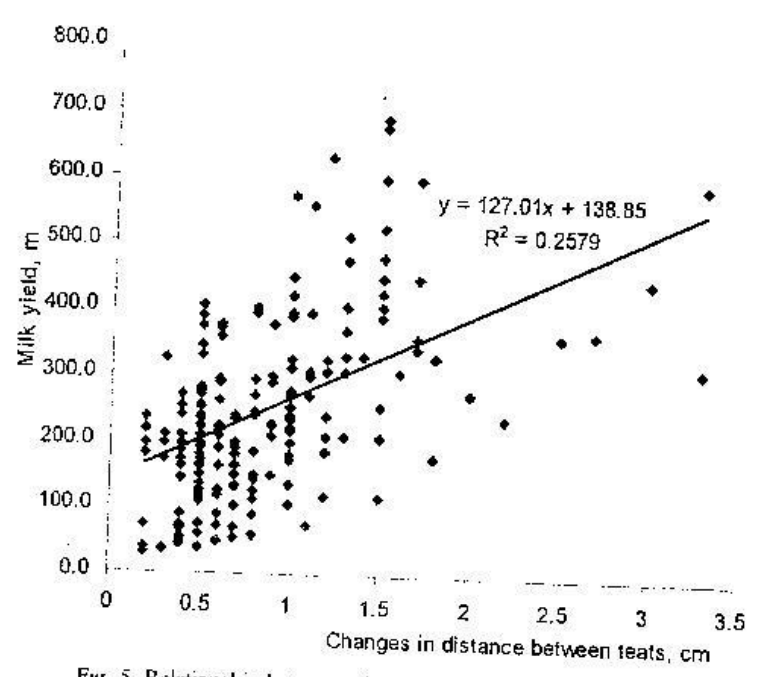

FIg. 5. Relationship between changes in distance betiven teats and inilk yield in goats

yield and udder dimensions with progress of lactation in this study. Linzell (1966) further pointed out that after the initial rapid decrease in udder volume in the first $2-3$ weeks of lactation, there is a more gradual decrease and much greater variation from animal to animal. The observed decreasing trends in mean estimates of udder circumference, distance between teats and milk yield with progress of lactation corroborate the findings of James and
Osinowo (2004) on West African Dwarf and Red Sokoto goats. Peris et al. (1999) attributed decrease in udder circumference to decrease in udder volume and milk yield in Damascus goats. Decrease in distance between teats may have been caused by diminution in teat angle which Peris et al. (1999) attributed to tissue distention as a consequence of the weight of the milk and the intensive use of milking machine or suckling activity of kids and their repeated pulling of tissues. In relation to parity, does of higher parity order tended to have wider udder circumference and distance between teats, as well as higher estimates of milk yield compared with primiparous does. It has been demonstrated by Knight and Peaker (1982) that in older goats, a proportion of mammary alveoli that developed in previous lactations did not regress completely but was added to those which developed in the subsequent lactation, thereby increasing the volume of the udder, particularly the secretary parenchyma. Interestingly, udder volume was shown to be positively associated with udder Table 3: Correlation coefficients among udder measurements and milk
yield in goats

\begin{tabular}{lllll}
\hline & UC & CUC & DBT & CDT \\
\hline UC & 1.000 & & & \\
CUC & $0.673^{* * *}$ & 1.000 & & \\
DBT & $0.757^{* * *}$ & $0.485^{* * *}$ & 1.000 & \\
CDT & $0.450^{* * *}$ & $0.528^{* * *}$ & $0.519^{* * *}$ & 1.000 \\
Milk yield & $0.759^{* * *}$ & $0.690^{* * *}$ & $0.498^{* * *}$ & $0.508^{* * *}$ \\
\hline UC- udder circumference before milking: DBT- distance between teats before milking; CUC- change in udder \\
circunference (UC. before milking minus UC after milking): CDT- change in distance between teats (DBT before \\
milking minus DBT after milking): \\
$* * * P<0.001$
\end{tabular}

